Jungbunlauer AG

Postfach 546, Schwarzenbergplatz 16, A-1011

Wien

Tel: 0222657636 Tlx: 131800

Produce citric acid and ethanol by

fermentation.

Ministry for Land and Forestry

Bundesministerium fur Land- und

Forstwirtschaft, stubenring 1, A-1010 Wien

Co-ordinating a biomass energy programme as part of the European rural energy network.

\section{Rumpel $\mathrm{GmbH}$}

Seillerstrasse 16, A-1015 Wien

Tel: $022252 \quad 1574$ Tlx: 011429

Supply water treatment, filtration and sewage treatment plant.

Ruthner Industrieanglagen AG

Aicholzgasse 51-53, A-1120 Wien

Tel: 0222839501 Tlx: 131273

Manufactures, designs and constructs process plant for fermentation and water treatment, as well as composting plant for treatment of garbage and sewage.

Technical University of Graz

Institut fur Biotechnologie, Mikrobiologie und Abfalltechnologie, Schlogelgasse 9, A-8010 Graz

Thermostrom Kesselwerk

Ennser Strasse 91, A-4407 Steyr

Tel: 72528271 Tlx: 28228

Manufacture precombustion furnaces, hot water boilers and heat exchangers as well as supplying various types of internal combustion engines.

\section{UNIDO}

United Nations Industrial Development Organisation, PO Box 3000, A-1400 Vienna Tel: 26310 Tlx: 135612

Co-ordinates international activities and disseminates information in all aspects of industrial technology and provides information through data bases and abstracting services.
University of Technology Vienna

Institute fur Verfahrenstechnik, Department of Chemical Engineering, Getriedemarkt 9, A-1060 Wien

Have developed a wood chip combustor for domestic heating purposes.

University of Vienna

Institute of Plant Physiology, Althanstrasse $14, \mathrm{~A}-1090$ Wien

Tel: 0222314510

Carrying out studies on basic physiology and photosynthesis in $\mathrm{C}-3$ and $\mathrm{C}-4$ plants in relation to biomass productivity.

Voest-Alpine Bausysteme $\mathrm{GmbH}$

Vereinigte Osterreichische Eisen und

Stahlwerke-Alpine Mont AG, Wienerstrasse 17, A-4020 Linz

Tel: 07225851 Tlx: 2209252 va-a

Manufacture composting plants and clarifying plants for industrial wastewaters. Parent company of Vogelbusch, Voest-Alpine and Bohler Brothers (US) who offer alcohol technology.

\section{Vogelbusch GmbH}

Postfach 52, Blechturmgasse 11, A-1053 Wien Tel: 0222541661 Tlx: 132144

Provide engineering and technical services for fermentation and distillation applicable to power alcohol (ethanol). Also offer plant for yeast (bakers' fodder), vinegar, potable alcohol, water treatment, anaerobic digestion, citric acid, acetic acid, singlecell protein, etc. Manufacture a deep jet process for microbial treatment of sewage. Produce an analytical detection system for on-line measurement and control of ethanol concentration during fermentation.

Zweigwerk Osterreich A-4673 Gaspoltshofen Tel: 07735284 Tlx: 27781 Suppliers of Spanex Sander GmbH \& Co KG (FRG) briquetters.

\title{
BANGLADESH
}

\author{
Al-Kamal \& Co \\ PO Box 593, Dhaka 2 \\ Provide consultancy services for the \\ installation of biogas plants for energy self- \\ sufficient villages. Also conduct training \\ courses and technical supervision programmes \\ for construction of family size plants and \\ publish a newsletter called Biogas Sangbad.
}

Bangladesh Agricultural University Department of Crop Botany, Mymensingh Tel: 219162

Researching crops as a source of fuels. 